\title{
Turriculate gastropods (Coelostylinidae) from the Esino limestone outcrop (Ladinian, Lombardy) of the Stoppani Collection housed at the Museo Civico di Storia Naturale, Milan (Italy)
}

\author{
Vittorio Pieroni
}

\begin{abstract}
Here, I propose a revision of 19 specimens of turriculate gastropod (family Coelostylinidae) from the Esino limestone formation (Ladinian). They form part of the surviving material of the historic Stoppani Collection, which was almost totally destroyed in the Second World War. The collection is kept at the Museo Civico di Storia Naturale in Milan, Italy. The specimens have already been described by Garassino (1992) but without a critical revision of their classification. Indeed, based on presumed likenesses with specimens reconstructed in Paléontologie Lombarde (Stoppani, 1858-60), Garassino believed he had rediscovered many of Stoppani's holotypes. For his classification of the material, Garassino consulted a revision by Kittl (1899) but he did not take into account the much more realistic drawings of the Stoppani's holotypes that Kittl published therein. A more detailed study, conducted by comparing the shapes and dimensions of the specimens with the drawings and original descriptions, and their reclassification, reveals that none of the specimens are, in actual fact, a holotype or more correctly a specimen described and illustrated by Stoppani, and that some have been assigned the wrong label. Nevertheless, the material and original handwritten labels are confirmed to be from Stoppani's studies.
\end{abstract} Milan

Key words: Gastropoda, Coelostylinidae, Ladinian, Stoppani,

Riassunto - Gasteropodi turricolati (Coelostylinidae) della formazione del Calcare di Esino (Ladinico, Lombardia) della Collezione Stoppani conservata presso il Museo Civico di Storia Naturale, Milano (Italia).

In questo articolo viene proposta la revisione di 19 esemplari di gasteropodi turricolati (Famiglia Coelostylinidae) della formazione del Calcare di Esino (Ladinico), inclusi nel materiale superstite della storica Collezione Stoppani, quasi totalmente distrutta durante la Seconda Guerra Mondiale. Tale materiale è conservato nel Museo Civico di Storia Naturale di Milano. Gli esemplari in questione furono già pubblicati da Garassino 1992, come semplice catalogazione, senza una revisione critica del materiale. Garassino identificò vari esemplari come olotipi di Stoppani, sulla base di somiglianze con quelli figurati come disegni ricostruttivi nella Paléontologie Lombarde (Stoppani, 1858-1860). Per riclassificare questo materiale Garassino utilizzò la revisione di Kittl

Museo Scientifico Naturalistico “A. Stoppani”, Seminario Arcivescovile "Pio XI", Via Papa Pio XI 32, 21040 Venegono Inferiore (VA), Italia

E-mail: info@marianopieroni.it

(C) 2016 Vittorio Pieroni

Received: 5 April 2016

Accepted for publication: 11 July 2016
1899, ma non usò i disegni assai più realistici ripubblicati da Kittl degli stessi esemplari figurati da Stoppani. Uno studio più approfondito degli esemplari presi in esame da Garassino 1992, attraverso la riclassificazione, la comparazione della loro forma e dimensione con le figure e le descrizioni originali, dimostra che nessuno di essi è stato figurato da Stoppani e/o da Kittl ed in alcuni casi manca la corretta combinazione tra esemplare e cartellino originale. Tuttavia questo materiale e i relativi cartellini autografi originali vengono confermati come derivanti dalle ricerche di Stoppani.

Parole chiave: Gastropoda, Coelostylinidae, Ladinico, Stoppani, Milano.

\section{INTRODUCTION}

Stoppani's types, housed at the Museo Civico di Storia Naturale, Milan, Italy were almost totally destroyed by an incendiary bomb during WWII. The turriculate gastropods (family Coelostylinidae) described in the present article, which are only part of what has been salvaged over the years of Stoppani's original collection, were included by Garassino (1992) in a catalogue together with other material from the limestone formation of Esino. This small collection of Triassic molluscs was found by Prof. Silvio Renesto when he was museum curator at the Istituto di Geologia e Paleontologia, University of Milan. They had probably been left there for safekeeping by Ardito Desio before WWII, along with a number of Stoppani's other types (Hass, 1953; pag. 62).

Garassino prepared his catalogue without any critical revision of the specimens' classification and without checking whether they had been paired with the correct original label. As a result, Garassino thought that he had found many holotypes, based on similarities with drawings published by Stoppani (1858-1860) in his important monograph on the Ladinian limestone fossils of Esino.

Although Stoppani's illustrations were drawn "d'après nature" and life-sized, they are not always realistic; indeed, many are reconstructions of whole shells based on very fragmented specimens. Thus, it is difficult to identify which specimens are illustrated in these drawings. Garassino consulted a revision by Kittl (1899), but not Kittl's more realistic drawings of Stoppani's specimens, many of which had been redrawn life-size and showing the original fractures. 
In his monograph, Stoppani reported the estimated sizes of the gastropods (deduced from the pleural angle of the preserved whorls), describing them as if they were whole, coherently with his drawings. Thus, we can approximately calculate the real size of the specimens illustrated by Stoppani. It is possible that today a specimen presents as more incomplete and with new fractures, but it cannot be more complete or larger than the dimensions originally reported.

Unfortunately, a more in-depth examination reveals that there are no holotypes among these specimens, and that some have been erroneously paired with the original label. On the other hand, there are no doubts that the specimens and the old labels they were found with were prepared by Stoppani: this was evident upon exhaustive study of the many articles written by Stoppani and kept at museums in Milan, Lecco (Archivio Fondo Manoscritti dei Musei Civici di Lecco) and Venegono (Museo Scientifico Naturalistico “A. Stoppani”), which have conserved his original manuscripts, palaeontological and geological specimens and memorabilia, all part of a collection housed at the ancient Seminario Minore di Monza, where the scientist from Lecco had been a seminarist (see Pieroni, 2014).

Nonetheless, it is hard to reconstruct the history of this material. Moreover, of the many new invertebrate species of the Triassic that Stoppani established, very few seem to be still present at the museums. Thus, the aim of the present study is to establish neotypes as substitutes for the lost holotypes.

About the application of the term "holotype", Stoppani, as well as many workers of the $19^{\text {th }}$ century, did not designate holotypes, so it is more correct to name these "specimens described by Stoppani".

As written by Stoppani on the original labels, the specimens are from Esino Lario (Grigna group, Lombardy), probably from the surrounds of "Passo Cainallo"; they are aged to the Mid-Triassic, Upper Ladinian, Longobardian (for a stratigraphic reference, please see Rossi Ronchetti 1959 ; 1960).

\section{TAXONOMIC REMARKS ON COELOSTYLINID GASTROPODS}

Coelostylinidae is the most problematic family among Mid-Triassic Caenogastropoda. Many recent studies have shown that this group is clearly polyphyletic (Nützel, 1998; Ponder et al., 2008). A distinction between genera such as Omphaloptycha and Coelostylina has been discussed by many authors without coming to any clear conclusion (Kittl, 1894, 1899; Böhm, 1895; Cossmann, 1909; Jaworsky, 1923; Zittel, 1924; Diener, 1926; Kutassy, 1937, 1940; Körner, 1937; Wenz, 1938; Haas, 1953; Batten \& Stokes, 1986; Nützel \& Senowbari-Darian, 1999; Nützel \& Douglas, 2004; Bandel, 2006).

The genus that Stoppani cited mainly for his Esino limestone turriculate gastropods is Chemnitzia Orbigny, 1939. It is still valid for extant forms of the Pyramidellidae family (opisthobranchs) of the Mediterranean, but not for those from the Mesozoic. Von Ammon (1892-93) established the genus Omphaloptycha and discussed the genus Chemnitzia, distinguishing between the two. Kittl $(1894 ; 1899)$ decided to abandon the latter because of the peculiar characteristics of the discovered Triassic forms. The genera adopted in Kittl (1899) have remained the references of choice for many years in the classical literature, and in lieu of the necessary complete revision of the Coelostylinidae, they have been utilized here too.

\section{Re-identification of the turriculate gastropods from the Esino limestone of the Stoppani Collection housed at the Museo Civico di Storia Naturale di Milano}

The pairing of the 19 Esino limestone turriculate gastropods - which are part of the Stoppani Collection housed at the Museo Civico di Storia Naturale in Milan - with the accompanying labels (written by Stoppani and by others) is first briefly described and discussed. The material is then compared with data deriving from Stoppani's and Kittl's illustrations. Information on the specimens housed at the Museo Civico di Storia Naturale di Milano is listed schematically as follows: catalogue number, corresponding picture in Fig. 1 of the present work, height of the specimen, transcription of the label hand written by Stoppani and

\footnotetext{
Fig. 1 - Captions of the 19 specimens studied in the present work, giving Stoppani's classification on his handwritten labels, Garassino's 1992 classification within square brackets, and the new classification proposed here, based on the systematics in Kittl 1899. Scale bar $=1 \mathrm{~cm}$. a) MSNM i12950 Chemnitzia retrozonata [Omphaloptycha escheri]. New classification: Chemnitzia fusus Stoppani = var. of Omphaloptycha escheri (Hoernes). b) MSNM i12954 Chemnitzia Breislakii [Omphaloptycha princeps]. New classification: internal mould not determinable. c) MSNM i12956 Trochus Ambrosini [Undularia ambrosinii]. New classification: Coelostylina conica (Muenster). d) MSNM i12957 Chemnitzia sphinx [Euchrysalis sphinx]. New classification: Euchrysalis sphinx (Stoppani). e) MSNM i12959 Trochus Fedrighini [Coelostylina conica]. New classification: Omphaloptycha escheri (Hoernes). f) MSNM i12963 Nerinea megaspira [Coelochrysalis megaspira]. New classification: Coelochrysalis megaspira (Stoppani). g) MSNM i12969 Chemnitzia lictor [Undularia brocchii]. New classification: Undularia (Toxoconcha) telescopia (Böhm). h) MSNM i12971 Chemnitzia turris [Omphaloptycha turris]. New classification: Omphaloptycha turris (Stoppani). i) MSNM 112972 Chemnitzia Maironi [Omphaloptycha maironi]. New classification: Omphaloptycha maironi (Stoppani). j) MSNM i12977 Chemnitzia uniformis [Undularia uniformis]. New classification: Undularia (Toxoconcha) uniformis (Stoppani). k) MSNM i12980 Chemnitzia exilis [Trypanostylus geographicus]. New classification: Chemnitzia exilis Stoppani = Trypanostylus geographicus? (Stoppani). 1) MSNM i12981 Chemnitzia trochiformis [Undularia concava]. New classification: Coelostylina conica (Muenster). m) MSNM i12985 Chemnitzia peracuta [Omphaloptycha peracuta]. New classification: Omphaloptycha peracuta (Stoppani). n) MSNM i12994 Chemnitzia lanceata [Omphaloptycha inflata]. New classification: Omphaloptycha inflata (Stoppani). o) MSNM i12995 Chemnitzia angulata [Omphaloptycha angulata]. New classification: Omphaloptycha escheri var. angulata (Stoppani). p-q) MSNM i12998 Chemnitzia antizonata [Omphaloptycha turris] (q: base). New classification: Undularia (Toxoconcha) uniformis (Stoppani). r) MSNM i12999 Phasianella Striato-Punctata [Coelostylina striatopunctata]. New classification: Coelostylina striatopunctata (Stoppani). s) MSNM i13008 lacking an original label [Undularia uniformis]. New classification: Undularia (Toxoconcha) jaculum (Stoppani). t) MSNM i13012 lacking an original label [Omphaloptycha peracuta]. New classification: Omphaloptycha peracuta (Stoppani).
} 

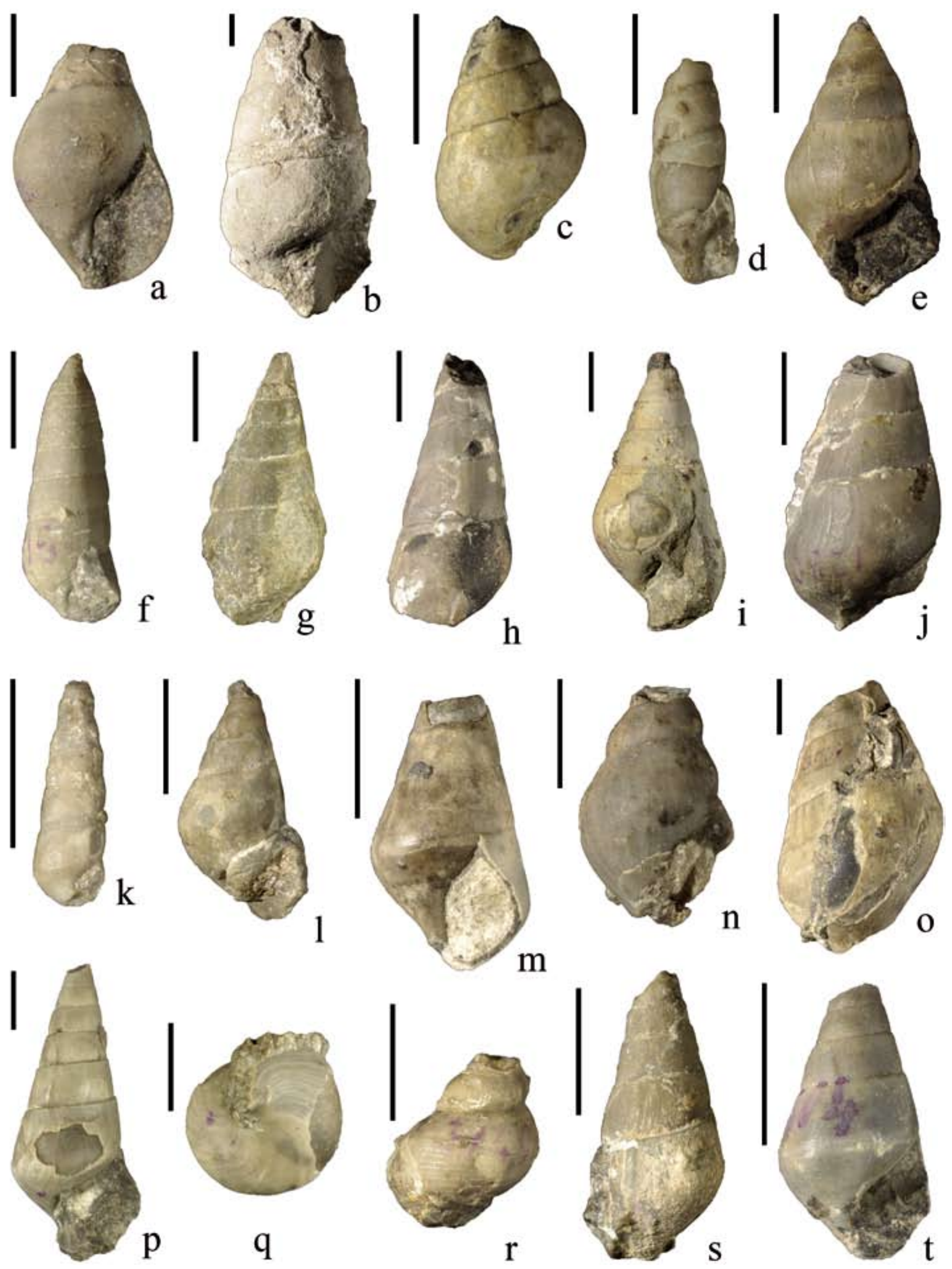
paired with the specimen (Stoppani Label), transcription of the label hand written by an unknown person and paired with the specimen (Anonymous Label); transcription of the label written by Alessandro Garassino and paired with the specimen (Garassino Label). Information on Stoppani's described specimens (Stoppani, 1858-60) is presented as follows: bibliographical reference given by Stoppani; height of the described specimen, as estimated by Stoppani [Estimated Height (Stoppani)]; pleural angle of the Stoppani's described specimen (Pleural Angle); and height of the non-reconstructed Stoppani's described specimen, as obtained from illustrations in Kittl (1899) [Height (from Kittl, page and figure number)]. Each item ends with a brief discussion and the conclusions reached.

Note on the taxonomic nomenclature used by Stoppani

Stoppani established a number of species in 1857 , but because none of the specimens were illustrated, it is possible to obtain all information about the same specimens, in his 1858-60 publication, in which he gave complete descriptions and figures of the new species.

When Stoppani named a new species after an Italian, he maintained the -i suffix of the surname without adding a second "i" (e.g., Fedrighini rather than Fedrighinii). For species dedicated to a person with a non-Italian surname, he first translated it into Latin (e.g., Breislak is Latinised to Breislakius) and then transformed it into the genitive case (e.g., Breislakii). This procedure is still considered acceptable (ICZN 1999, Article 31.1.1).

Family Coelostylinidae Cossmann, 1909

Genus Coelochrysalis Kittl, 1894

Coelochrysalis megaspira (Stoppani, 1858)

Specimen: MSNM i12963 - Figs. 1f and 2.

Height: $25 \mathrm{~mm}$ (= whole specimen).

Stoppani Label: Nerinea megaspira Stopp. pl. 8, fig 3. 3130 .

Anonymous Label: not present.

Garassino Label: Coelochrysalis megaspira, Olotipo. Esino. Triassico Superiore.

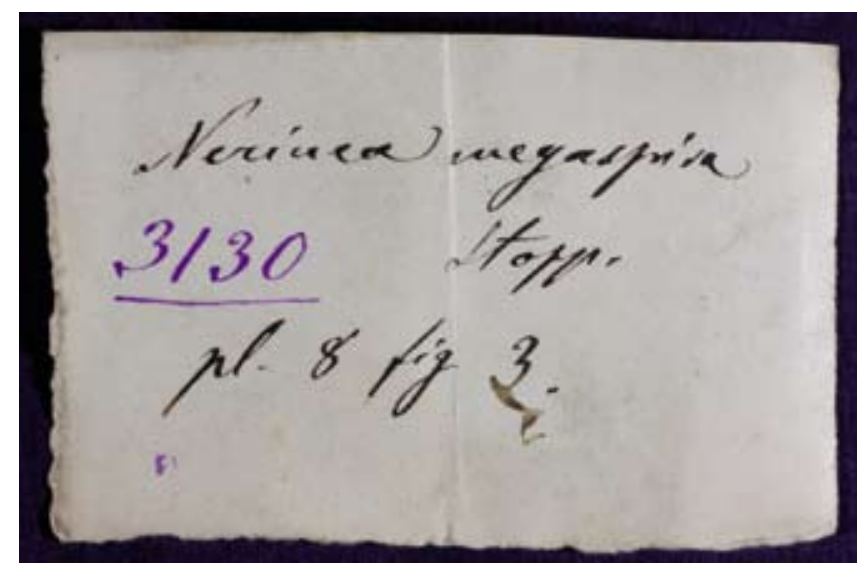

Fig. 2 - The label for MSNM i12963, Nerinea megaspira, hand written by Stoppani.
Specimen described by Stoppani: Nerinea megaspira Stoppani, 1858-60, pag. 36, pl. 8, fig. 3.

Estimated Height (Stoppani): $35 \mathrm{~mm}$.

Pleural Angle: $11^{\circ}$; Apical Angle: $42-35^{\circ}$.

Height (from Kittl 1899, pag. 175): specimen not illustrated or described.

Discussion: MSNM i12963 is well preserved and complete, but only $25 \mathrm{~mm}$ high; it corresponds with $\mathrm{Ne}$ rinea megaspira. The number written on it is the same as that on the original label.

Conclusion: There are insufficient elements to establish whether this specimen is the specimen described by Stoppani or not. Its dimensions are significantly smaller than those given by Stoppani.

Genus Coelostylina Kittl, 1894

Coelostylina conica (Muenster, 1841)

Specimen: MSNM i12956 - Fig. 1c.

Height: $18 \mathrm{~mm}$ (= final 4 whorls).

Stoppani Label: Trochus Ambrosini Stopp. pl. 12, fig. 16. 3156 .

Anonymous Label: Omphaloptycha ambrosinii

Garassino Label: Undularia ambrosinii, Olotipo. Esino. Triassico Superiore.

Specimen described by Stoppani: Trochus Ambrosini Stoppani, 1858-60, pag. 57, pl. 12, fig. 16.

Estimated Height (Stoppani): $24 \mathrm{~mm}$.

Pleural Angle: $58^{\circ}$.

Height (from Kittl 1899, pag. 160; fig. 88): $26 \mathrm{~mm}$ (last 4 whorls), but the drawing was probably enlarged slightly.

Discussion: MSNM i12956 is very different from Trochus Ambrosini. It has rounded, smooth whorls, whereas T. Ambrosini has a sharp angle at the middle of the whorl, and an axial and spiral sculpture. The specimen is very similar to Coelostylina conica.

Conclusion: MSNM i12956 is not the Stoppani's described specimen of Trochus Ambrosini.

Specimen: MSNM i12981 - Fig. 11.

Height: $21 \mathrm{~mm}$ (= almost complete specimen).

Stoppani Label 1: Chemnitzia trochiformis Klipst. pl. 7, figs. 12 e 18.3066. 3066.

Stoppani Label 2: Chemnitzia trochiformis Klipst.

Anonymous Label 1: Trochus fedrighini. Coelostylina (Coelostylina) conica (Münst.).

Anonymous Label 2: Omphaloptycha trochiformis (Stopp.).

Garassino Label: Undularia concava, Olotipo. Esino. Triassico Superiore.

Specimen illustrated: Chemnitzia trochiformis Klipstein. In Stoppani, pag. 29, pl. 7, figs. 12, 18.

Estimated Height (Stoppani): $24 \mathrm{~mm}$.

Pleural Angle: $39^{\circ}$. 
Height (from Kittl 1899, pag. 159; fig. 87): $23 \mathrm{~mm}$ (specimen almost whole).

Discussion: MSNM i12981 is similar in dimensions to, but very different from the specimen in Kittl 1899 , fig. 87, and seems more similar to Coelostylina conica, as given on one of the anonymous labels. The pseudoshell is poorly preserved, so exact classification results problematic. There are probably too many labels for this specimen.

Conclusion: There are insufficient elements to establish whether this specimen is one of those illustrated by Stoppani.

\section{Coelostylina striato-punctata (Stoppani, 1858)}

Specimen: MSNM i12999 - Fig. 1r.

Height: $15.5 \mathrm{~mm}(=2.5$ preserved whorls $)$.

Handwritten label (probably not Stoppani's): Phasianella Striato-Punctata Stopp. Pag. 61. Pl. 10, figs. 1314. 3149 .

Anonymous Label: Coelostylina striatopunctata (Stopp.). La calligrafia del foglietto che accompagna l'esemplare non mi sembra quella di Stoppani. [The handwriting on the label accompanying this specimen does not seem to be Stoppani's].

Garassino Label: Coelostylina striatopunctata, Olotipo. Esino. Triassico Superiore.

Specimen described by Stoppani: Phasianella StriatoPunctata Stoppani, 1858-60, pag. 61, pl. 10, figs. 13-14.

Estimated Height (Stoppani): $32 \mathrm{~mm}$.

Pleural Angle: $40^{\circ}$.

Height (from Kittl 1899, pag. 145; fig. 75): 19 mm (last 4 whorls).

Discussion: The specimen illustrated in Kittl 1899 (pag. 145, fig. 75) does not have the dimensions stated by Stoppani. The figure may have been reduced. Kittl's drawing and text give clear indication of the presence of growth lines, which are not visible in Stoppani's illustration or on the specimen. MSNM i12999 is rather similar to Stoppani's description of Coelostylina striatopunctata, but it does not have the dimensions of the specimen described by Stoppani and does not correspond with Kittl's figure, in which the specimen has a pleural angle of $50^{\circ}$ instead of the $43^{\circ}$ of the present specimen, which is closer to that given by Stoppani $\left(40^{\circ}\right)$.

Conclusion: MSNM i12999 is not the specimen described by Stoppani of Coelostylina striatopunctata, but it does correspond with the species, as described and illustrated by Stoppani.

Genus Euchrysalis Laube, 1870

Euchrysalis sphynx (Stoppani, 1857)

Specimen: MSNM i12957 - Fig. $1 \mathrm{~d}$.

Height: $21.5 \mathrm{~mm}$ (= last 3 whorls).

Stoppani Label: Chemnitzia sphinx Stopp. pl. 6, figs. 11-12. 3062 .
Anonymous Label: not present.

Garassino Label: Euchrysalis sphinx, Olotipo. Esino. Triassico Superiore.

Specimen described by Stoppani: Chemnitzia sphinx Stoppani, 1858-60, pag. 25, pl. 6, figs. 11-12.

Estimated Height (Stoppani): $25 \mathrm{~mm}$.

Pleural Angle: $10^{\circ}$; Apical Angle: $25^{\circ}$.

Height (from Kittl 1899, pag. 178; fig. 105): $27 \mathrm{~mm}$ (specimen almost complete), but the drawing was probably enlarged slightly.

Discussion: The dimensions of MSNM i12957 are similar to the specimen described by Stoppani, but the fractures are clearly different. The number written on the specimen is the same as that on Stoppani's original label.

Conclusion: MSNM i12957 belongs to Chemnitzia sphinx, but it is not the specimen described by Stoppani.

Genus Omphaloptycha Ammon, 1892 (1893)

Omphaloptycha turris (Stoppani, 1857)

Specimen: MSNM i12971 - Fig. 1h.

Height: $40 \mathrm{~mm}$ (= last 5 whorls).

Stoppani Label: Chemnitzia turris Stopp. pl. 1, fig. 2-3. 1224. Esino.

Anonymous Label: Toxoconcha turris (Stopp.).

Garassino Label: Omphaloptycha turris, Olotipo. Esino. Triassico Superiore.

Specimen described by Stoppani: Chemnitzia turris Stoppani, 1858-60, pag. 15, pl. 1, fig. 2.

Estimated Height (Stoppani): $53 \mathrm{~mm}$.

Pleural Angle: $20^{\circ}$.

Height (from Kittl 1899, pag. 109; fig. 36): $39 \mathrm{~mm}$ (last 4.5 whorls).

Discussion: C. turris is illustrated by Stoppani in pl. 1, fig. 2, while C. Cainalli, shown in fig. 3, became synonymous with Omphaloptycha turris in Kittl (1899). Specimen MSNM i12971 has high affinity with Chemnitzia turris illustrated by Kittl 1899 (fig. 36, pag. 110). The fractures are different.

Conclusion: MSNM i12971 corresponds with Chemnitzia turris, but is not the specimen described by Stoppani.

Omphaloptycha peracuta (Stoppani, 1857)

Specimen: MSNM i12985 - Fig. $1 \mathrm{~m}$.

Height: $20 \mathrm{~mm}$ (= final 3 whorls), but specimen MSNM

i13012 (Fig. 1t), whose number corresponds with that on Stoppani's label, is $16 \mathrm{~mm}$ high (= last 4 whorls) .

Stoppani Label 1: Chemnitzia peracuta Stopp. Tav. 7, fig. 29. 1204. Esino.

Stoppani Label 2: Ch. peracuta Stopp. pl. 7, fig. 29.

Anonymous Label: not present.

Garassino Label: MSNM i12985 Omphaloptycha peracuta, Olotipo. Esino. Triassico Superiore. MSNM 
i13012 Omphaloptycha peracuta, Paratipo, Esino. Triassico Superiore.

Specimen described by Stoppani: Chemnitzia peracuta Stoppani, 1858-60, pag. 34, pl. 7, fig. 29.

Estimated Height (Stoppani): $23 \mathrm{~mm}$.

Pleural Angle: $30^{\circ}$.

Height (from Kittl 1899, pag. 117; fig. 47): $27 \mathrm{~mm}$ (specimen almost complete), but the drawing has probably been slightly enlarged.

Discussion: Stoppani's first label refers to MSNM i13012, and quotes the old number 1204. However, neither specimen corresponds with the figures in Kittl 1899.

Conclusion: Neither of the two specimens corresponds with the specimen described by Stoppani.

Omphaloptycha escheri (Hoernes, 1856)

Specimen: MSNM i12959 - Fig. 1e.

Height: $30 \mathrm{~mm}$ (=last 5 whorls).

Stoppani Label 1: Trochus Fedrighini Stopp. pl. 12, figs. 9-10. 1237.

Stoppani Label 2: Trochus Fedrighini? Stopp. pl. 12, figs. 9-10. 1237. Esino.

Anonymous Label: Coelostylina (Coelostylina) conica (Münst.).

Garassino Label: Coelostylina conica, Olotipo. Esino. Triassico Superiore.

Specimen described by Stoppani: Trochus Fedrighini Stoppani, 1858-60, pag. 55, pl. 12, figs. 9-10.

Estimated Height (Stoppani): $21 \mathrm{~mm}$.

Pleural Angle: $44^{\circ}$.

Height (from Kittl 1899, pag. 142; fig. 70): $23 \mathrm{~mm}$ (specimen almost complete), but the drawing was probably enlarged slightly.

Discussion: MSNM i12959 is too large compared with the specimen described by Stoppani. Moreover, it corresponds with Omphaloptycha escheri rather than Coelostylina conica. There is no number on the specimen.

Conclusion: The specimen is not correctly paired with Stoppani's original label, and does not seem to resemble any of the specimens described and illustrated by Stoppani.

Omphaloptycha escheri var. fusus (Stoppani, 1858)

Specimen: MSNM i12950 - Fig. 1a

Height: $30 \mathrm{~mm}$ (= last 2 whorls).

Stoppani Label: Chemnitzia retrozonata Stopp. pl. 6 , fig. 7. 1228 Esino.

Anonymous Label: not present.

Garassino Label: Omphaloptycha escheri, Olotipo. Esino. Triassico Superiore.

Specimen described by Stoppani: Chemnitzia retrozonata Stoppani, 1858-60, pag. 23, pl. 6, fig. 7.

Estimated Height (Stoppani): $35 \mathrm{~mm}$.

Pleural Angle: $40^{\circ}$.
Height (from Kittl 1899, pag. 122; fig. 49): $27 \mathrm{~mm}$ (last 2 whorls), but the drawing was probably enlarged slightly.

Discussion: MSNM i12950 is $30 \mathrm{~mm}$ high and $20 \mathrm{~mm}$ wide. It is composed of the last two whorls. The size of the specimen is larger than that described by Stoppani. Moreover, the shapes of the whorls and peristome are more similar to those of Chemnitzia fusus. However, the number written on the specimen corresponds with that on Stoppani's original label.

Conclusion: Specimen MSNM i12950 is not the specimen described by Stoppani of Chemnitzia retrozonata.

Omphaloptycha escheri var. maironii (Stoppani, 1857)

Specimen: MSNM i12972 - Fig. 1i.

Height: $48 \mathrm{~mm}$ (= specimen almost complete).

Stoppani Label: Chemnitzia Maironi Stopp. pl. 5, fig.

1. 1219. Esino.

Anonymous Label: Diventa sinonima di Coelostylina (Coelostylina) escheri (Hörn.).

Garassino Label: Omphaloptycha maironi, Olotipo. Esino. Triassico Superiore.

Specimen described by Stoppani: Chemnitzia Maironi Stoppani, 1858-60, pag. 20, pl. 5, fig. 1.

Estimated Height (Stoppani): $64 \mathrm{~mm}$.

Pleural Angle: $34^{\circ}$.

Height (from Kittl 1899, pag. 124; fig. 54): $62 \mathrm{~mm}$ (specimen almost complete).

Discussion: MSNM i12972 corresponds with Chemnitzia Maironi, but is too small with respect to the specimen described as the specimen described by Stoppani, and has different fractures.

Conclusion: There are insufficient elements to establish whether this specimen is the specimen described by Stoppani or not.

Omphaloptycha escheri var. angulata (Stoppani, 1858)

Specimen: MSNM i12995 - Fig. 10.

Height: $49 \mathrm{~mm}$ (= final 3 whorls).

Stoppani Label: Chemnitzia angulata Stopp. pl. 6, fig.

3. 3037.

Anonymous Label: Coelostylina (Coelostylina) escheri var. angulata (Stopp.).

Garassino Label: Omphaloptycha angulata, Olotipo. Esino. Triassico Superiore.

Specimen described by Stoppani: Chemnitzia angulata Stoppani, 1858-60, pag. 22, pl. 6, fig. 3.

Estimated Height (Stoppani): $53 \mathrm{~mm}$.

Pleural Angle: $38^{\circ}$.

Height (from Kittl 1899, pag. 125; fig. 55): $51 \mathrm{~mm}$ (last 3 whorls).

Discussion: Kittl's drawing seems to have been enlarged: the height of the 3 preserved whorls is $51 \mathrm{~mm}$, with an estimated height of $64 \mathrm{~mm}$, whereas the estimated height in Stoppani is only $53 \mathrm{~mm}$. MSNM 112995 is com- 
posed of slightly more than 2 whorls, and has a height of $49 \mathrm{~mm}$, with an estimated height of over $70 \mathrm{~mm}$; thus, it is too large. The old catalogue number it bares is the same as that written on the label by Stoppani.

Conclusion: MSNM i12995 is not the Stoppani's specimen of Chemnitzia angulata. However, this specimen corresponds with $C$. angulata $=$ Omphaloptycha escher $i$ var. angulata, as described in Kittl (1899).

\section{Omphaloptycha inflata (Stoppani, 1857)}

Specimen: MSNM i12994 - Fig. $1 \mathrm{n}$.

Height: $23 \mathrm{~mm}$ (= last 3 whorls). 27.

Stoppani Label: Chemnitzia lanceata Stopp. pl. 7, fig.

St.

Anonymous Label: Coelostylina (Coelostylina) inflata

Garassino Label: Omphaloptycha inflata, Olotipo. Esino. Triassico Superiore.

Specimen described by Stoppani: Phasianella inflata Stoppani, 1858-60, pag. 60, pl. 13, fig. 7.

Estimated Height (Stoppani): $44 \mathrm{~mm}$.

Pleural Angle: $40^{\circ}$.

Height (from Kittl 1899, pag. 130; fig. 58): $33 \mathrm{~mm}$ (last 2 whorls).

Discussion: Stoppani's described specimen of Phasianella inflata has an estimated height of $44 \mathrm{~mm}$. The specimen is $23 \mathrm{~mm}$ high, with a possible estimated height of $30 \mathrm{~mm}$. Kittl's specimen (fig. 58, pag. 130), which has only 2 preserved whorls, has a height of $33 \mathrm{~mm}$ and an estimated height of $50 \mathrm{~mm}$. The pleural angle in Stoppani is $40^{\circ}$. The zig-zag pattern of pigmentation described by Stoppani is not visible on the specimen. The holotype of Chemnitzia lanceata has an estimated height of $29 \mathrm{~mm}$ in Stoppani, and in Kittl (fig. 98, pag. 164) corresponds with Undularia (Toxoconcha) brocchii, which is significantly different from this specimen. Thus, MSNM i12994 is not paired correctly with its original label. Neither the specimen nor the Stoppani label it comes with bares the original catalogue number.

Conclusion: On account of the complex history of this specimen and its labels, it is impossible to establish whether it is the specimen described by Stoppani or not. MSNM i12994 corresponds with Phasianella inflata Stoppani $=$ Omphaloptycha inflata, as per the description in Kittl (1899).

Genus Undularia Koken, 1892

Subgenus Toxoconcha Kittl, 1899

Undularia (Toxoconcha) uniformis (Stoppani, 1858)

Specimen: MSNM i12977 - Fig. 1j.

Height: $29 \mathrm{~mm}$ (= last 3 whorls).

Stoppani Label 1: Chemnitzia uniformis Stopp. pl. 7 , fig. 23. 1230.

Stoppani Label 2: Chemnitzia Uniformis Stopp. pl. 7, fig. 23. 1230. Esino.
Anonymous Label: not present.

Garassino Label: Undularia uniformis, Olotipo. Esino. Triassico Superiore.

Specimen described by Stoppani: Chemnitzia uniformis Stoppani, 1858-60, pag. 32, pl. 7, fig. 23.

Estimated Height (Stoppani): $38 \mathrm{~mm}$.

Pleural Angle: $28^{\circ}$.

Height (from Kittl 1899, pag. 168; fig. 99): $33 \mathrm{~mm}$ (last 4 whorls).

Discussion: The height of the final 3 preserved whorls of MSNM i12977 corresponds with that of the last 3 whorls of the specimen described by Stoppani, which, however, is composed of 4 whorls. It is possible that the specimen became further damaged, gaining new fractures, rendering it different to that given in Kittl's illustration. The specimen corresponds with Chemnitzia uniformis.

Conclusion: There are insufficient elements to establish whether this specimen is the specimen described by Stoppani or not.

Specimen: MSNM i12998 - Fig. 1p,q.

Height: $48.5 \mathrm{~mm}$ (= almost complete specimen).

Stoppani Label: Chemnitzia antizonata Stopp. pl. 4, fig. 6. 3038 .

Anonymous Label: not present.

Garassino Label: Omphaloptycha turris, Olotipo. Esino. Triassico Superiore.

Specimen described by Stoppani: Chemnitzia antizonata Stoppani, 1858-60, pag. 19, pl. 4, fig. 6.

Estimated Height (Stoppani): $46 \mathrm{~mm}$.

Pleural Angle: $24^{\circ}$.

Height (from Kittl 1899, pag. 109-110; fig. 37): 41 mm (last 4 whorls).

Discussion: The almost complete specimen MSNM i12998 does not correspond with that illustrated by Kittl (fig. 37, pag. 110), which has only 4 whorls. The growth lines are clearly different: in MSNM i12998, they are highly sigmoidal, similar to those of Undularia (Toxoconcha), whereas they are axial and straight in $C$. antizonata $=$ Omphaloptycha turris var. antizonata. The specimen corresponds rather highly with Undularia (Toxoconcha) uniformis (Stoppani), see Kittl (1899) pl. 12, fig. 28. The catalogue number on Stoppani's original label is not legible on the specimen.

Conclusion: MSNM i12998 is not paired with the correct Stoppani label. None of the Stoppani's specimens illustrated by Kittl (1899) correspond with this specimen.

\section{Undularia (Toxoconcha) telescopia (Böhm, 1895)}

Specimen: MSNM i12969 - Fig. 1g.

Height: $30 \mathrm{~mm}$ (= specimen almost complete).

Stoppani Label: Chemnitzia lictor Stopp. pl. 5, fig 3.

1218. Esino.

Anonymous Label: not present.

Garassino Label: Undularia brocchii, Olotipo. Esino. Triassico Superiore. 
Specimen described by Stoppani: Chemnitzia lictor Stoppani, 1858-60, pag. 20, pl. 5, fig. 3.

Estimated Height (Stoppani): $80 \mathrm{~mm}$.

Pleural Angle: $25^{\circ}$.

Height (from Kittl 1899, pag. 163): specimen not illustrated or described.

Discussion: Stoppani's holotype is cited by Kittl (1899) who, thinking it too fragmented, hypothesized a similarity with Undularia (Toxoconcha) telescopia (Böhm). However, MSNM i12969 is represented by an almost complete shell and corresponds with Undularia (Toxoconcha) telescopia.

Conclusion: There are insufficient elements to establish whether this specimen is the specimen described by Stoppani or not. Its dimensions are significantly smaller than those given by Stoppani.

\section{Undularia (Toxoconcha) jaculum (Stoppani, 1858)}

Specimen: MSNM i13008 - Fig. 1s.

Height: $25 \mathrm{~mm}$ (= last 4 whorls).

Stoppani Label: not present.

Anonymous Label: not present.

Garassino Label: Undularia uniformis, Olotipo. Esino. Triassico Superiore.

Remarks: This specimen is clearly not Undularia uniformis. Rather, it seems to be Undularia (Toxoconcha) jaculum (Stoppani), as per the figure in Kittl 1899 (pag. 169, fig. 100).

Stoppani's estimated height of his specimen of Undularia (Toxoconcha) jaculum (pag. 33, pl. 7, fig. 28) is 30 $\mathrm{mm}$, and the pleural angle is $29^{\circ}$.

The height of the same specimen of Undularia (Toxoconcha) jaculum derived from Kittl's figure of an unreconstructed specimen is $27 \mathrm{~mm}$ without the initial whorls, and so corresponds to the size given by Stoppani.

Discussion: This specimen lacking Stoppani's original label seems very similar in size and shape to the specimen of Undularia (Toxoconcha) jaculum illustrated in Kittl (1899) as the Stoppani's original specimen, even if the initial whorls are somewhat more damaged.

Conclusion: There are insufficient elements to establish this specimen as the specimen described by Stoppani of Undularia (Toxoconcha) jaculum.

Family Spirostylidae Cossmann, 1909

Genus Trypanostylus Cossmann, 1895

Trypanostylus geographicus (Stoppani, 1858)

Specimen: MSNM i12980 - Fig. 1k.

Height: $14 \mathrm{~mm}$ (= specimen almost complete).

Stoppani Label: Chemnitzia exilis Stopp. pl. 7, fig. 8. 3045.

Anonymous Label: not present.

Garassino Label: Trypanostylus geographicus, Olotipo. Esino. Triassico Superiore.
Specimen described by Stoppani: Chemnitzia exilis Stoppani, 1858-60, pag. 28, pl. 7, fig. 8.

Estimated Height (Stoppani): $17 \mathrm{~mm}$.

Pleural Angle: $15^{\circ}$.

Height (from Kittl 1899, pag. 96; fig. 29): 12 mm (last 6 whorls).

Discussion: MSNM i12980 is slightly larger than the specimen described by Stoppani, and the fractures are different. The specimen corresponds with Chemnitzia exilis $=$ Trypanostylus geographicus .

Conclusion: There are insufficient elements to establish whether this specimen is the specimen described by Stoppani or not.

Internal mould not determinable

Specimen: MSNM i12954 - Fig. $1 \mathrm{~b}$.

Height: $101 \mathrm{~mm}$ (=last 3 whorls).

Stoppani Label: Chemnitzia Breislakii Stopp. pl. 4, figs. 2-3. 3040.

Anonymous Label: not present.

Garassino Label: Omphaloptycha princeps, Olotipo. Esino. Triassico Superiore.

Specimen described by Stoppani: Chemnitzia Breislakii Stoppani, 1858-60, pag. 16, pl. 3, fig. 5.

Estimated Height (Stoppani): $193 \mathrm{~mm}$.

Pleural Angle: $33^{\circ}$.

Height (from Kittl 1899, pag. 132, fig. 64): $74 \mathrm{~mm}$ (last 3 whorls).

Specimen described by Stoppani: Chemnitzia Collegni Stoppani, 1858-60, pag. 18, pl. 4, figs. 2-3.

Estimated Height (Stoppani): $171 \mathrm{~mm}$.

Pleural Angle: $21^{\circ}$.

Height (from Kittl 1899): specimen not drawn.

Discussion: There is an error in Stoppani's (1858-60) caption of pl. 4, figs. 2-3: "Chemnitzia Breislakii" was written instead of "Chemnitzia Collegni", and described on pag. 18. Therefore, it is possible that the label was prepared at a later date taking into account the figure and not the text. The specimen is not numbered. Moreover, the specimen is completely different from the drawing of Chemnitzia Breislakii published by Kittl (1899).

Conclusion: This bad preserved internal mould does not correspond with the specimen described by Stoppani of Chemnitzia Breislakii, and corresponds only difficulty with the specimen described by Stoppani of Chemnitzia Collegni.

\section{Acknowledgements}

Firstly, I would like to thank Dr. Alessandro Garassino and Dr. Giorgio Teruzzi from the Museo Civico di Storia Naturale di Milano; the former because he was willing to rediscuss his 1994 publication, and the latter for his help in preparing the present work and for making the photographs published herein. I'm also grateful to the reviewers Stefano Monari (Padova University) and Alexander Nützel (Munchen University) for their thoughtful reviews. 


\section{REFERENCES}

Ammon L. von, 1892 (1893) - Die Gastropoden des Hochfellen-Kalkes und über Gastropoden-Reste aus Ablagerungen von Adnet, von Monte Nota und den Raibler Schichten. Geognostiche Jahreshefte, Kassel, 5: 161-219.

Bandel K., 2006 - Families of the Cerithioidea and related superfamilies (Palaeo-Caenogastropoda; Mollusca) from the Triassic to the Recent characterized by protoconch morphology - including the description of new taxa. Freiberger Forschungshefte, Paläontologie, Stratigraphie, Fazies, 14 (C 511): 59-137.

Batten R.L. \& Stokes W.L., 1986 - Early Triassic Gastropods from the Sinbad Member of Moenkopi Formation, San Rafael Swell, Utah. American Museum novitates; no. 2864. American Museum of Natural History, New York, 2864: 1-33.

Bohm J., 1895 - Die Gastropoden des Marmolatakalkes. Palaeontographica, Stuttgart, 42: 211-308.

Cossmann M., 1909 - Essais de paléoconchologie comparée. Presses Universitaires de France, Paris, 8: $1-248$.

Diener C., 1926 - Glossophora triadica: Fossilium Catalogus 1, Animalia. W. Junk, Berlin, 34: 1-242.

Garassino A., 1992 - Catalogo dei tipi del Museo Civico di Storia Naturale di Milano. XI. I molluschi fossili del Calcare di Esino della Collezione Stoppani. Atti della Società Italiana di Scienze Naturali e Museo Civico di Milano, 133 (18): 245-260.

Haas O., 1953 - Mesozoic invertebrate faunas of Peru. Bulletin of the American Museum of Natural History, 101: 1-328.

International Commission on Zoological Nomenclature, 1999 - International Code of Zoological Nomenclature (ICZN). The International Trust for Zoological Nomenclature, London, fourth edition: 1-106.

Jaworski E., 1923 - Die marine Trias in Südamerika. In: Beiträge zur Geologie und Paläontologie von Südamerika. Steinmann G. (ed.). Neues Jahrbuch für Mineralogie, Geologie und Paläontologie, Stuttgart, suppl. 47: 93-200.

Kittl E., 1894 - Die triadischen Gastropoden der Marmolata und verwandter Fundstellen in den weissen Riffkalken Südtirols. Jahrbuch der Kaiserlich Königlichen Geologischen Reichsanstalt, 44: 99-182.

Kittl E., 1899 - Die Gastropoden der Esinokalke nebst einer revision der Gastropoden der Marmolatakalke. Annalen des k.k. Naturhistorischen Hofmuseums, 14: $1-237$.

Körner K., 1937 - Marine (Cassianer-Raibler) Trias am Nevado de Acrotambo (Nord-Peru). Palaeontographi$c a, 86$ (A): 145-237.

Kutassy E., 1937 - Triadische Faunen aus dem Bihar-Gebirge: Geologica Hungarica, ser. Paleont., 13: 1-18.

Kutassy E., 1940 - Glossophora triadica: Fossilium Catalogus 1, Animalia. W. Junk, Berlin, 81: 243-477.

Nützel A., 1998 - Über die Stammesgeschichte der Ptenoglossa (Gastropoda). Berliner Geowissenschaftliche Abhandlungen, Reihe E 26: 1-229.

Nützel A. \& Senowbari-Daryan B., 1999 - Gastropods from the Late Triassic (Norian-Rhetian) Nayband For- mation of central Iran. Beringeria, Würzburg, 23: 93132.

Nützel A. \& Douglas H., 2004 - Late Triassic (Late Norian) gastropods from the Wallowa Terrane (Idaho, USA). Paläontologishe Zeitschrift, 78 (2): 361-416.

Pieroni V., 2014 - I fossili raccolti da Antonio Stoppani conservati nel museo del Seminario Pio XI di Venegono Inferiore. Emi-Grafica: 1-64.

Ponder W.F., Colgan D.J., Healy J.M., Nützel A., Simone L.R.L. \& Strong E.E., 2008 - Caenogastropoda. In: Phylogeny and evolution of the Mollusca. Ponder W.F. \& Lindberg D.L. (eds.). University of California Press, Berkeley, Los Angeles, London, 331-383.

Rossi Ronchetti C., 1959 - Il Trias in Lombardia. I: Lamellibranchi ladinici del Gruppo delle Grigne. Rivista Italiana di Paleontologia e Stratigrafia, Milano, 65: 269-356.

Rossi Ronchetti C., 1960 - Il Trias in Lombardia. II: Cefalopodi ladinici del Gruppo delle Grigne. Rivista Italiana di Paleontologia e Stratigrafia, Milano, 66: $1-64$.

Stoppani A., 1857 - Studii geologici e paleontologici sulla Lombardia. C. Turati, Milano, 1-458.

Stoppani A., 1858-60 - Les Pétrifications d'Esino ou description des fossiles appartenants au dépôt triasique supérieur des environs d'Esino en Lombardie. Paléontologie lombarde, 1: 1-151.

Wenz W., 1938 - Gastropoda. Handbuch der Paläozoologie. Gebrüder Borntraeger, Berlin.

Zittel K.A. von, 1924 - Grundzüge der Paläontologie (Paläozoologie). Neubearbeitet von Dr. Ferdinand Broili. 1. Abteilung: Invertebrata. (Sixth edition). R. Oldenbourg Verlag, München. 